\title{
BROADER PERSPECTIVES ON THE INTEREST OF PENSION PLAN PARTICIPANTS
}

\author{
Edited by \\ Richard F. DeMong, CFA \\ McIntire School of Commerce \\ University of Virginia \\ William S. Gray III, CFA \\ Harris Trust and Savings Bank \\ Chicago, Illinois \\ Robert D. Milne, CFA \\ Duff \& Phelps Investment Management \\ Cleveland, Ohio
}

Monograph 22

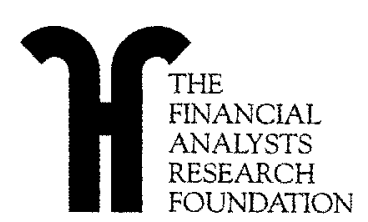


Copyright $\odot 1985$

by

The Financial Analysts Research Foundation

Charlottesville, Virginia

Printed in the United States of America

All Rights Reserved

ISBN 10-digit: 0-9721477-2-1 ISBN 13-digit: 978-0-9721477-2-9

\title{
Financial Analysts Research Foundation Monograph Series
}

\author{
Richard F. DeMong, CFA \\ Research Director
}

No. 18 Robert W. Kolb and Gerald D. Gay

No. 19 James E. Hatch and Robert W. White

No. 20 Robert H. Jennings

No. 21 Michael D. Atchison Richard F. DeMong, CFA and John L. Kling
Interest Rate and Stock Index Futures and Options: Characteristics, Valuation and Portfolio Strategies, 1985

Canadian Stocks, Bonds, Bills and Inflation: 1950-1983, 1985

Reaction of Financial Analysts to Changes in: Management Earnings Forecasts, 1985

New Financial Instruments: A Descriptive Guide, 1985 


\section{CONTENTS}

\section{Pages}

Preface

vi

Contributors

vii

Introduction

Serving the Interests of Participants

The Private and Public Pension Systems in

Relation to Saving, Investment and Growth James Tobin

Goals in an Inflationary World

Robert D. Milne, CFA

Funding Pension Liabilities: Employee

Versus Firm Perspectives

Robert S. Kemp, Fr., CPA

Who is the Victim Now?

39

Linda F. Martin and A. Fames Ifflander, CFA 


\section{Board of Trustees and Officers}

Alfred C. Morley, CFA, President

The Institute of Chartered

Financial Analysts

P.O. Box 3668

Charlottesville, Virginia 22903

James R. Vertin, CFA, Vice President

Alpine Counselors

136 Pecora Way

Menlo Park, California 94025

George W. Noyes, CFA, Secretary

Standish, Ayer \& Wood, Inc.

1 Beacon Street

Boston, Massachusetts 02116

Edus H. Warren, Jr., CFA, Treasurer

Capital Research Company

280 Park Avenue

New York, New York 10017

Richard F. DeMong, CFA, Research Director McIntire School of Commerce Monroe Hall, University of Virginia Charlottesville, Virginia 22903

John C. Burton

Columbia University

101 Uris Hall

New York, New York 10027

Charles A. D'A mbrosio, CFA, Ex Officio University of Washington

Graduate School of Business

Administration

Seattle, Washington 98195

M. H. Earp, CFA

Brittany Associates, Inc.

P. O. Box 26177

Dallas, Texas 75226

Charles D. Ellis, CFA

Greenwich Research Associates

Office Park Eight

Greenwich, Connecticut 06830

William S. Gray, III, CFA

Harris Trust \& Savings Bank

111 West Monroe Street

Chicago, Illinois 60690

Jay O. Light

Harvard Business School

Baker 331

Boston, Massachusetts 02163

Edmund A. Mennis, CFA

Consultant to Investment Management 405 Via Chico, Suite 7

Palos Verdes Estates,

California 90274
Robert D. Milne, CFA

Duff \& Phelps Investment

Management Co.

710 Ohio Savings Plaza

Cleveland, Ohio 44114

Roger F. Murray

P.O. Box 669

Wolfeboro, New Hampshire 03894

Matthias Plum, Jr.

Global Investments, L.P.

600 Atlantic Avenue, Suite 1400

Boston, Massachusetts 02110

William G. Shenkir, Ex Officio

McIntire School of Commerce

University of Virginia, Monroe Hall

Charlottesville, Virginia 22903

A. A. Sommer, Jr.

Morgan, Lewis \& Bockius

1800 M Street, N. W.

Washington, D. C. 20036

Walter P. Stern, CFA

Capital Research Company

280 Park Avenue

New York, New York 10017

Jack L. Treynor

Treynor-Arbit Associates

111 West Jackson Boulevard

Chicago, Illinois 60604

Donald L. Tuttle, CFA

Indiana University

Graduate School of Business

Bloomington, Illinois 47405

Jay Vawter, CFA, Ex Officio

Stein Roe \& Farnham

1271 Avenue of the Americas

New York, New York 10020

Chairman, Institute of Chartered

Financial Analysis

Ernest R. Widmann, CFA, Ex Officio Widmann, Blee \& Co. Incorporated One Station Circle

Narbeth, Pennsylvania 19072

Chairman, Financial Analysts

Federation

Arthur Zeikel

Merrill Lynch Asset

Management, Inc.

633 Third Avenue

New York, New York 10017 


\section{THE FINANCIAL ANALYSTS RESEARCH FOUNDATION AND ITS PUBLICATIONS}

1. The Financial Analysts Research Foundation is an autonomous charitable foundation, as defined by Section 501(c)(3) of the Internal Revenue Code. The Foundation seeks to improve the professional performance of financial analysts by fostering education, by stimulating the development of financial analysis through high quality research, and by facilitating the dissemination of such research to users and to the public. More specifically, the purposes and obligations of the Foundation are to commission basic studies (1) with respect to investment securities analysis, investment management, financial analysis, securities markets and closely related areas that are not presently or adequately covered by the available literature, (2) that are directed toward the practical needs of the financial analyst and the portfolio manager, and (3) that are of some enduring value. The Financial Analysts Research Foundation is affiliated with The Financial Analysts Federation, The Institute of Chartered Financial Analysts, and the University of Virginia through The McIntire School of Commerce.

2. Several types of studies and publications are authorized:

A. Studies based on existing knowledge or methodology which result in a different arrangement of the subject. Included in this category are papers that seek to broaden the understanding within the profession of financial analysis through reviewing, distilling, or synthesizing previously published theoretical research, empirical findings, and specialized literature;

B. Studies that apply known techniques, methodology, and quantitative methods to problems of financial analysis;

C. Studies that develop new approaches or new solutions to important problems existing in financial analysis;

D. Pioneering and original research that discloses new theories, new relationships, or new knowledge that confirms, rejects, or extends existing theories and concepts in financial analysis. Ordinarily, such research is intended to improve the state of the art. The research findings may be supported by the collection or manipulation of empirical or descriptive data from primary sources, such as original records, field interviews, or surveys.

3. The views expressed in this book and in the other studies published by the Foundation are those of the authors and do not necessarily represent the official position of the Foundation, its Board of Trustees, or its staff. As a matter of policy, the Foundation has no official position with respect to specific practices in financial analysis.

4. The Foundation is indebted to the voluntary financial support of its institutional and individual sponsors by which this and other publications are made possible. As a $501(\mathrm{c})(3)$ foundation, contributions are welcomed from interested donors, including individuals, business organizations, institutions, estates, foundations, and others. Inquiries may be directed to:

Research Director

The Financial Analysts Research Foundation

University of Virginia, Post Office Box 3665

Charlottesville, Virginia 22903

(804) 924-3051 


\title{
PREFACE
}

The mid-1980s have seen deficit spending reach an all time high and interest rates continue to fluctuate. The memories of doubledigit inflation of a few years ago have been revived by those who fear that it will occur again in these unstable economic times. In such a climate the prudent management of pension funds becomes all the more crucial.

The essays which comprise this monograph seek to awaken portfolio managers and other interested readers to the intricacies of pension fund planning. William S. Gray III, CFA, specifically examines some of the inter-relationships between real wages, the level and security of real retirement benefits, pension costs and corporate profits. James Tobin discusses Social Security and its relationship to private pension plans and to personal savings, while Robert D. Milne, CFA, examines inflation's effect upon private pension funds and on Social Security. Robert S. Kemp, Jr., CPA, questions whether its in the firm's shareholders or the pension plan's beneficiaries interest to fully fund the pension plan. Finally, Linda J. Martin and A. James Ifflander, CFA, discuss some of the current hot topics (plan termination and overfunding) of pension plan management and their impact on the pension plan beneficiaries. The implications of inflation are important even when the inflation rate is at a low level, since during the pension fund participant's lifetime, inflation will surely rise and fall from its current rate. All six authors consider the role that pension fund management plays in the economy as a whole. Their essays are an outgrowth of a conference on pension fund management held by the Financial Analysts Research Foundation and the current pension fund management controversy.

\author{
Richard F. DeMong, CFA \\ University of Virginia
}




\section{CONTRIBUTORS}

William S. Gray III, CFA, is Senior Vice President of Harris Trust and Savings Bank in Chicago. Mr. Gray received his $\mathrm{PhB}$ and his MBA from The University of Chicago. He joined the Bank in 1950 as a Securities Analyst. His professional endeavors have included serving as Chairman of The Financial Analysts Federation, Chairman of the Investment Committee at the American Bankers Association, and President of The Financial Analysts Research Foundation.

A. James Ifflander, CFA, is an Assistant Professor of Finance, Arizona State University. He has a Ph.D. from Michigan State University. $H$ is research interests include pensions and the anomalies in the efficient market hypothesis.

Robert S. Kemp, Jr., CPA, is an Associate Professor of Commerce, McIntire School of Commerce, University of Virginia. He has a DBA from Florida State University. His research interests include pension fund management and corporate financial management.

Linda J. Martin is an Assistant Professor of Finance, Arizona State University. She has a DBA from Louisiana Tech University. Her research interests include pensions and behavioral aspects of risk.

Robert D. Milne, CFA, is President of Duff \& Phelps Investment Management Co., Cleveland, Ohio. He is a past president of The Institute of Chartered Financial Analysts, and the Cleveland Society of Security Analysts and has served on the Editorial Boards of The CFA Digest and the Financial Analysts Fournal. He has a J.D. degree from Cleveland State University.

James Tobin is Sterling Professor of Economics at Yale University, where he has been a faculty member since 1950 . He was a Member of President Kennedy's Council of Economic Advisers in 1961-62. In 1981 he was awarded the Alfred Nobel Memorial Prize in Economic Science. He has over the years written widely on the subjects of saving, investment, portfolio choice, and asset pricing. 


\section{INTRODUCTION}

Trust law is largely devoted to the protection of those parties having a financial interest in a trust or an estate. Such protection is often necessary because many income beneficiaries and remaindermen have very little knowledge of those matters that are important to the care and preservation of assets. In addition, it has been long recognized that individuals who are given the responsibilities of carrying out the provisions of a trust agreement are likely to have some interests that do not correspond with those of the beneficiaries.

Given the historical concern that state law has had for those who are to receive benefits under a formal trust arrangement, it is not surprising that Congress worked toward the establishment of federal law to cope with the needs of participants of employee benefit plans. The federal law was enacted on September 2,1974 as the Employee Retirement Income Security Act of 1974 (ERISA). It states very clearly that administrators charged with fiduciary responsibilities of employee benefit plans are to act "solely in the interest of the participants."

Although the employee benefit plans are somewhat similar to personal trusts, there are some unique characteristics that should be recognized. One important similarity between them is that their respective participants and beneficiaries expect to receive payments at regular intervals over some period of time. Therefore, the adequacy of such payments will be significantly affected by what happens to the purchasing power of the dollar, particularly as it is affected by inflation. This is a problem that needs to be addressed more carefully than ever before due to the seemingly permanent nature of inflation since the late 1960 s.

One of the important differences between an employee benefit plan and most personal trusts is that the former will usually receive additional funds from the sponsoring corporation on a periodic basis. Indeed, such periodic contributions are likely to be essential if the retired participants are going to receive the payments to which they are entitled. Even good pension fund investment results are not likely to be sufficient to relieve completely the sponsor from any future contributions. Therefore, the participants have a genuine interest in the continuing well-being and viability of the sponsoring corporation. By contrast, in most personal trusts the in- 
vestment results alone will determine what is available for the beneficiary and remaindermen.

With the back-up insurance that is provided by the Pension Benefit Guaranty Corporation, it might be argued that the economic well-being of the sponsor is not important to the participants or at least not as important as was just indicated. In a very narrow sense, this may be so! Overall, however, the PBGC's ability to honor its insurance commitments is based on the premium payments due from the sponsors. If we don't have mostly healthy sponsors to pay the premiums, the capacity of $\mathrm{PBGC}$ to provide the insurance protection will be very much limited.

Another rather important difference between pension plan participants and personal trust beneficiaries is that the former must go through an extended period (while they are working) during which they receive no payments. During the period in which they are working, participants have a clear interest in the investment results of the employee benefit plan, which will affect its ability to meet the eventual retirement income payment obligations, and may also permit somewhat lower sponsor contributions that might otherwise have been required. Such a favorable impact on employment costs may be relevant to the sponsor's ability to be cost competitive. This could be an important fact with respect to future job security, especially in the case of those companies that are doing business in the "world market."

Because the participants in an employee benefit plan are all employed by a particular company (multi-employer union plans are an exception), that company, its employees, officers, directors and shareholders may have certain interests that don't coincide with those of the participants. Thus, there tends to be a much larger realm of potential conflicts-of-interest related to an employee benefit plan than is usually involved with a personal trust.

In view of the many differences between employee benefit plans and personal trusts, participants and beneficiaries, and the maturity of the laws which pertain to the respective fiduciary responsibilities involved, it seems appropriate to reflect upon the "interest of the participants" in employee benefit plans. Following are five papers which explore some of the more important implications of this rather telling phrase. Each of the authors has approached the issue from a distinctly different point of view. Each provides some "food for thought" for government policy makers, pension sponsors and those involved with the judicial aspects of employee benefit plan administration. 


\section{SERVING THE INTERESTS OF PARTICIPANTS}

\section{William S. Gray III, CFA}

Late in 1975, The Financial Analysts Research Foundation sponsored a one-day seminar entitled "Evolving Concepts of Prudence." At that time the meaning of fiduciary responsibility was undergoing unusually careful re-examination. Extensive new legislation had been adopted by the Congress in 1974. This Employee Retirement Income Security Act (ERISA) attempted to clarify who is a "fiduciary," the behavior expected of anyone serving in that capacity and certain principles of prudent investment management. It raised many questions, some of which were addressed at that meeting.

\section{Total Portfolio Focus}

Perhaps the issue of greatest moment at that time was how to appropriately determine what constitutes "prudence." Should each investment be viewed by itself or should primary attention be directed to the characteristics of the "total portfolio"? State laws were then still preoccupied with each individual investment. However, it had become increasingly clear that this represented an unfortunate case of "tunnel vision" - a view that didn't really best serve the interest of the participants of employee benefit plans and furthermore had some harmful effects on the entire economy. Several of the speakers offered strong encouragement for the "total portfolio" view. Subsequently, the Department of Labor has indicated that, in making a particular investment, a fiduciary must consider the role it plays in the portfolio, to determine that its role as part of the portfolio is reasonably designed to further the purposes of the plan. ${ }^{1}$

That particular issue provides an example of the prompt recognition of an enlightened view. Of course, this "total portfolio" approach did not threaten the interests of any group that might otherwise have marshalled strong opposition. In fact, it had some political support because it was expected to improve the market for the securities of smaller companies (which has happened), thereby encouraging new product development and greater competition for large, established corporations.

See DOL “Investment Duties," effective July 23, 1979. 
While the views on this issue did reflect breadth of perspective, the same was much less true of the views expressed on "the sole interest of the participants." Much of the commentary on the latter appeared to equate the ability to meet pension obligation payments almost entirely with very moderate (if not low) risk taking in the pension portfolio. One speaker stated that "the objective of a pension fund should be the same as those of the typical investor accumulating savings during the working years so as to provide for the retirement years." 2 Another stated: "In a defined benefit plan, risk taking primarily affects the employer's cost; the employee gets no immediate benefit from a high return." 3

\section{Congressional Intent}

In drafting ERISA the Congress was quite concerned that many employees were losing retirement benefits. Therefore, the basic policy thrust of the Act was to protect the interests of participants in employee benefit plans. Of course, much of the earlier loss of anticipated retirement benefits was due to a lack of vesting provisions or the termination of plans, not investment losses per se! Such disappointments (and some were quite serious) resulted from widespread misunderstanding of the provisions pertaining to most pension plans prior to ERISA.

Although disappointments resulting from vesting and termination provisions were the primary concern, it was only natural that something about investment losses be included: "a fiduciary must diversify the plan's investments so as to minimize the risk of large losses." Like "motherhood," such pious statements are best left unchallenged in the public arena. Yet, such a statement probably reflects some lack of understanding on what may be necessary to meet significant pension obligations in real terms without a major setback in current wages. Some recognition of that fact was reflected in the statement, "A simplistic view of what is in the interest of the individual participant is clearly unrealistic and inappropriate: indeed, it will be significantly harmful."4

\footnotetext{
2 "Evolving Concepts of Prudence," Robert D. Milne, p. 45.

3 "Evolving Concepts of Prudence," Robert W. Murphy, p. 13.

$4 \quad$ "Evolving Concepts of Prudence," William S. Gray, p. 79.
} 


\section{Economic Realities}

Developments over the past nine years provide much to consider in determining what is really in the interest of the participants. The diversification away from U.S. equities - to fixed-income securities that began in 1975 - has been quite harmful, so far! But of much greater importance, the competitive problems of certain industries (e.g., television sets, automobile and steel manufacturing) and the diminished productivity of the U.S. economy have enormous implications for retirement income benefit programs. If we are unable to produce goods and services which can be sold at competitive prices to make a reasonable profit, our ability to make pension contributions and the value of pension assets will be seriously jeopardized.

As an aside, it seems likely that government statistics understate "productivity" just as they overstate "inflation." While the Bureau of Labor Statistics has adjusted the CPI to remove the mortgage interest and housing cost biases, a more fundamental problem remains. Such indices measure price increases, not all of which represent inflation. Inflation is only that portion of a price increase for which nothing is received (by anyone) in return. Higher prices have increasingly reflected indirect payments for cleaner air and water, safer factories, more comfortable work places, government services paid for by business taxes, etc. All of this is on top of product quality improvements that oftentimes necessitate higher prices which do not reflect inflation.

Even though our productivity experience may not have been as bad as the government statistics suggest, it seems fairly clear that we are losing position in many areas of world trade and this is having a weakening affect on a good many U.S. corporations. The impact this has on job security and the ability to fund pension contributions is not favorable.

\section{Productivity, Pensions and Wages}

Of course, the productivity issue should be examined, not only from the standpoint of the job security hazards that arise if we fail to remain competitive with others, but from the standpoint of "opportunity loss" as well. To illustrate, let us consider the implications of the difference that one-half of one percent per annum can make in the retirement payments a pensioner would receive under a typical private pension plan. Take the case of an individual who works for forty-one years (say from age 22 to 62 ) and whose retirement payments are based on the average level of pay during the last five years of work. 
It is worth examining the implications in both real terms and in nominal terms. Starting with wages at an index figure of 100 in the first year, let us focus on the outcomes between the thirty-seventh and forty-first years of eligible employment, i.e., the last five years.

Since pensions are paid in nominal dollars and are based upon wages that were paid in nominal dollars, it seems best to concentrate on the nominal income growth figures; a five and one-half percent constant rate of inflation has been assumed. If the nominal wage had grown for forty years at eight and one-half percent instead of eight percent, the individual's real retirement income would be close to twenty percent higher as a result of working in this environment. Using the same base rate (eight percent) as the point of departure, it may be noted that an extra one percent per annum (nine percent) growth would result in retirement payments that were fortytwo percent higher and an extra two percent per annum (ten percent growth) would produce payments that were 101 percent higher.

A corollary of such increased real income retirement benefits is the greater stream of real wages along the way, e.g., during the working years. A person that starts at $\$ 10,000$ per year $(\$ 5 / \mathrm{hr}$. $)$ and experiences increases of eight percent per annum for 40 years would collect about $\$ 2.8$ million in wages or salary. The same person, with increases of eight and one-half percent per annum (an extra one-half percent per annum in real terms) would collect over $\$ 3.2$ million in wages or salary. While this extra $\$ 400,000$ is hardly like winning an equal amount all at one time in the lottery (say after twenty years on the job and buying who knows how many $\$ 1$ lottery tickets), it is not insignificant.

Clearly, productivity in the U.S. has implications for income while on the job and after retirement. It also has implications for relative assurance that such payments can be made and to the real value of the amounts involved. Since a person who works for fortyone years and lives for fifteen years in retirement is a "participant" throughout the combined fifty-six year time period, he (or she) will be greatly impacted by what is going on throughout those years. Yes, the "interest of the participants" extends way beyond the assets held in a particular pension fund at any given time. Furthermore, it extends beyond the Pension Benefit Guaranty Corporation. The longer-term health of the economy and real productivity improvements lie at the center of the participants' vital interests. 
support the notion that savings as a percent of income, investment as a percentage of GNP and the rate of improvement in labor productivity are very closely related..$^{5}$ During the past decade or so, Japan has had relatively high numbers in each of these categories. The U.S. and Canada have been relatively low, especially the U.S.! While the close relationship does not establish cause and effect, it is absolutely consistent with the causal linkage suggested above.

\section{Savings - Need vs. Motivation}

If savings and investment are so closely related to productivity, we need to encourage them. But how is this to be accomplished? What is it that really causes people (or businesses) to save and invest? As with most human behavior, cultural and familiar influences are probably at work. The most salient of these can be expressed in the everyday terms that include: 1) fear of employment (and income) interruption; 2) desire to consume more expensive items; 3) desire to establish the potential to consume in the future (even if not working); and 4) the return (after tax) that people will receive for doing so, thereby enlarging future consumption potentials.

The elevation of social programs within our society has been manifesting itself in many ways. There are programs to provide unemployment compensation, subsidized housing, medical and hospital services and retirement income (including social security). Each of these addresses one or more of the first three human needs that ordinarily motivate saving. Therefore, it would seem reasonable to assume that the expansion of social institutions has had a dampening effect on savings and investment. There have been a number of studies indicating that this dampening effect has been quite severe. ${ }^{6}$

Perhaps it is more than coincidence that the enhancement of social programs has been accompanied by some erosion in the real after-tax returns from productive assets. Such programs have involved increased taxation (direct, indirect and/or via inflation). Direct taxes have an impact on what you are allowed to keep, indirect taxes on the size of investment income payments received, while inflation reduces the real value of future payments. Is it any

5 Center for Policy Research, American Council for Capital Formation. (See the Appendix of this Chapter).

6 Martin Feldstein, "The Effects of Social Security on Private Savings", NBER Working Papers 314 and 334, 1978-79. 
wonder we have a problem? If we had set out to destroy productivity, could we have devised a more effective prescription?

Of course, it is easier to identify a problem than it is to come up with a workable solution. Is there any solution to the savings, investment and productivity deficiencies within the U.S.? Can these deficiencies be alleviated without a major reduction in our social commitments? No one can be sure. However, since our society has expressed its concerns for people through programs that reduce (or eliminate) the need to save, we may need to re-examine whether our concerns are legitimate and whether there are program modifications that would help restore the need to save. That will be a very difficult task. In the meantime, we can certainly address the motivations for saving.

The Reagan Administration appears to be concerned about the motivations to save and invest, but not as an end in itself. Rather, savings and investment are perceived as a primary means to restore our competitive position on a world-wide basis, increase job security, create more jobs to accommodate a growing number of persons who want jobs and to improve the standard of living for everyone. They also play a critical role in something as mundane as our ability to provide retirement income benefits (through social security and the private pension system) in real terms - which brings us back to the "interests of the participants" in the management of pension funds.

\section{Investment Returns and Pension "Cost"}

To set the stage, it should be helpful to recall the person who starts to work for $\$ 10,000$ a year, has increases of eight percent each year and collects about $\$ 2.8$ million over a forty-one year span. His (her) average annual income during the last five years of employment would be approximately $\$ 187,350$. (If that seems outlandish, it merely demonstrates what happens if a five and one-half percent to six percent rate of inflation continues over a long period of time.) If retirement income benefits are set at sixty percent of average pay for the final five years, this retiree will receive $\$ 112,414$ per year. Assuming a life expectancy of fifteen years, a rate of return of nine percent (three and one-half percent over the inflation rate) and a fully-funded situation, the amount needed to provide such income payments will be about $\$ 906,056$ at retirement.

There are many ways sanctioned by actuaries to accumulate that amount $(\$ 906,056)$ during the forty-one years of active employment. However, to keep it simple, we shall assume a rate of return on in- 
vestment of nine percent per annum and a company contribution that remains a constant percentage of the participant's wages: an annual contribution of $\$ 841$ during the first year, scaling on up to $\$ 18,268$ in the forty-first year. Sponsor contributions would total $\$ 326,105$ over the forty-one year period, equal to about twenty-six percent of the total amount needed $(\$ 906,056)$ on the date of retirement. All the rest comes in the form of investment return!

The above represents a very straightforward analysis of the pension "cost" factor for a single employee, given the stated assumptions. It matches the total "cost" against revenues of the employer during the years of active employment. It is not manipulated by the choice of funding methods (Unit Credit, Entry Age Normal, etc.) sanctioned by the actuaries. It does not allow for the possible benefit of forfeitures that may very well arise within a group retirement plan situation. It is about as pure as the driven snow!

While everyone understands that differences in rates of return on pension investments have an impact on pension "cost," it may be useful to review just how significant this impact can be.

Using the same basic assumptions on salary increases, etc., a seven percent rate of return on investment would require contribu-

TABLE 2

Investment

Rate of Return Per Annum

1. Present worth of $\$ 1$ per period for 15 years

2. Fund required to pay $\$ 112,414 / \mathrm{yr}$. for 15 years

3. Contributions required as a \% of salary to produce the fund required (See \#2)

4. Contributions

in \$'s

1st Year

41 st Year

All 41 Years

5. Total contributions as \% of fund required at retirement (See \#2)
$\$ 1,023,855$

$\$ 906,056$

$\$ 808,346$

$\$ 726,464$

6.4624

7.1908

8.0607

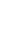

.

.


tions at 13.77 percent of salary, while a rate of return of thirteen percent would require contributions at only 2.87 percent of salary. The difference between a nine percent and an eleven percent rate of return would mean a difference between 8.41 percent and 4.98 percent in contributions as a percentage of salary. In the context of corporate profits, the difference between a nine percent and an eleven percent return on pension investments would translate into about two percentage points of pretax margins (assuming wages and salaries were about one-half of company revenues). These are very significant "cost" differentials.

Although "cost" savings from favorable investment returns may or may not filter through to the bottom line, they are very likely to be in the "interest of participants." If offset by lower prices, these savings permit an improved competitive position relative to other producers. If offset by $R \& D$ expenditures, better business or manufacturing cost savings should develop in the future. If they do reach the "bottom line," they should have a favorable impact on federal tax revenues and provide additional funds for investment in new plant and equipment, e.g., helping to curtail government deficits and improve productivity.

\section{Pension "Profit Centers"?}

This kind of focus on potential "cost" savings may seem to harken back to the 1960's when certain pension sponsors treated the company's pension fund as a "profit center." Many of those sponsors who did so increased risk taking (devoting higher percentages to common stocks, including more "high flyers") in the period immediately preceding a five year disaster for the stock market (1969 to 1974). The motives were questionable and the results spoke for themselves.

Although that particular approach to "cost" savings was illadvised, the present realities make it very clear that we must be concerned about the costs of doing business - all the costs of doing business. Our world has changed dramatically since the late 1960's. At that time unnecessary (or excessive) costs were viewed primarily as damaging to shareholders. Ho hum! But now their direct threat to job security, employment opportunities, etc. is becoming recognized. That places the issue of pension cost savings in an entirely different light, especially in the political arena. "Cost" reduction through prudent risk taking should be quite acceptable, even in court! 


\section{Bonds or Equities?}

A few years ago some sponsors addressed the "cost" problem by shifting heavily, or entirely, in to fixed-income securities. The relatively high current income from such instruments somehow justified a higher actuarial rate assumption, thereby permitting some reduction in current contributions. Unless invested in very short-term maturities, such portfolios were victimized by some extraordinarily bad bond markets. Although legitimized by the existing "rules of the game," these sponsors appeared to be seeking short-run "cost" reduction at the risk of higher costs in the long run: if common stocks produce higher returns than fixed-income securities over the long run, ultimately contributions would have to become much larger as a consequence of this fixed-income policy decision. That was before the Fischer Black bombshell ${ }^{7}$ which certainly has not detonated, but has not been defused. More on that shortly!

Based on the view of a pension fund standing by itself, those investments that produce greater returns should help lower pension "cost." Common stocks (or other types of equity exposure) should be beneficial, if not held in amounts exceeding prudent diversification standards, which do vary from one pension fund to another. Accordingly, the "asset allocation" decision has emerged as the primary policy issue. The decision with respect to the basic debt-equity mix is recognized as the most important. It will have the greatest impact on the average rate of return of the pension portfolio. For most pension funds, the impact will significantly exceed that which comes about through the selection of particular equity or fixed-income managers. Thus, it may not be in the "interest of the participants" to spend more on the selection and monitoring of individual managers than is spent on the appropriate "asset allocation" decision and its continuing assessment.

\section{Pension Funds Don't Exist in a Vacuum}

Just as the traditional focus of the "prudent man" has shifted from each issue to the "total portfolio," it seems that the pension fund should no longer be viewed by itself. Although pension assets are not "available" to the corporate sponsor under normal circumstances (terminated plans that are overfunded represent an exception), it seems clear that their experience will have a significant 
impact on the "cost" exposure of the company. As pension funds grow in relation to the net worth of pension sponsors, this impact becomes even greater. Therefore, the implications for competitive position, job security, $R \& D$, capital expenditures and value of the firm have become magnified. Such compelling arguments notwithstanding, the idea is very controversial. It leads to a whole set of issues having to do with how (if at all) pension assets and liabilities should be reflected in corporate financial statements.

In spite of these uncomfortable "side effects," the issue will not (and should not) go away. Pension funds have become very important from every conceivable point of view. Their role in helping to sustain retired employees, their impact on the "cost" of doing business, competitive position, job security and cash-flow are quite apparent and closely interrelated. The "interest of the participants" cannot be viewed realistically through a narrow tunnel. It must be seen as a vital part within a much larger organic system, with ongoing "feedback" between the pension plan and the sponsoring firm.

\section{"Tax Arbitrage" and Value of the Firm}

The Fischer Black perspective represents a case in point! Simply stated, it addresses some of the implications of the existing tax laws in the U.S. Since dividends received by a corporation are virtually exempt from taxation while interest paid is fully deductible, it would appear advantageous to issue debt for the purpose of acquiring equity securities, except for one thing: this would expose the company to increased risk. Professor Black suggests that this negative aspect can be offset by shifting the assets of the company's pension fund out of common stocks and into bonds. Since a "qualified" plan is completely tax exempt, there are no tax reasons to prefer stocks over bonds. Presumably, this would reduce the risk of the pension portfolio.

In his view, this "tax arbitrage" represents an irresistible plan to increase the value of the firm without increasing the risk. Clearly, it assumes that "the market" takes into account a company's pension situation when judging its value. There is some evidence that stock prices are sensitive to changes in a company's unfunded pension liabilities. ${ }^{8}$ Therefore, it would seem reasonable to suppose that the market would be sensitive to important changes in the character, e.g., risk, of pension assets.

8 Mary Greenebaum, "The Market Has Spotted Those Pension Problems," Fortune, December 1, 1980, p. 143. 
There seem to be many reasons why the idea has not taken hold. Normal resistance to change and reservations about "the market" perception of enhanced earning power and unchanged risk are among them. The latter may be justified, at least in normal financial market circumstances.

Some particular pension funds may already have enough (or too much) bond exposure. For the many funds that do not, consideration should focus on the amount of additional bonds that would seem warranted, not a complete substitution of bonds for equities. The latter would seem ill-advised just on the basis of prudent diversification principles. In addition, the problems we have had with "unexpected" inflation during this past decade should serve as a more than ample reminder of the characteristics of bonds. Fixed rate obligations can adjust only by declining in price. Common stocks normally adjust (though perhaps with a lag) through larger increases in earnings and dividends. This cushions the price dampening effect of higher discount rates under increasingly inflationary circumstances.

With the real "interest of the participants" in mind, there is one further thought on the greater use of bonds, especially when in pursuit of the "tax arbitrage" benefits. It certainly need not be avoided simply because it may enhance the value of the firm. If greater value is the result, it would undoubtedly reflect other benefits that are of real interest to all employees, active or retired. Furthermore, given current circumstances, the Tobin's "q" (the ratio of market price to replacement book value) for common stocks is diminishing the investment of funds in new machinery and equipment. Enormous quantities of corporate funds are being used to acquire other companies "at a discount." If common stocks were selling closer to (or above) replacement value, more of these corporate funds would presumably flow into new capital projects.

\section{Dedicated Portfolios}

What about "dedicated bond portfolios" (a segregated component of a plan's pension assets to provide exclusively for the retired participants)? The idea has been heavily promoted in recent years. Whether it is appropriate must depend on the circumstances. If it is adopted as part of a careful judgment that more bonds and a higher actuarial rate assumption are truly in the "interest of all participants," it may be entirely proper. However, if it is adopted as a 
means to disguise what amounts to an increased actuarial rate assumption, without some rationale as to why a corresponding increase in the wage growth rate assumption is not appropriate, it is certainly open to suspicion. For example, it could be perceived as a move that directly diminishes the pension assets available for retired employees. Also, it might be perceived as a move to choke contribution flows!

\section{Social Investment}

The entire thrust of this paper has been to encourage (and maybe even help provide) a broad perspective in considering the real "interest of the participants" - the well-being of individual workers and their families, not just for today and tomorrow, but over their lifetimes. It relates directly to what could be described as a meaningful social concern. If that is the case, we might consider for just a moment exactly how this fits into, or conflicts with, the "social investment" issue.

This particular issue has many different aspects. Space permits only a few comments on that aspect which is encouraging the investment of pension funds locally, i.e., in that area "closest to home" to the participants in a particular plan. Local investment is advocated by those who argue that northern union pension funds should not be invested in southern nonunion companies. ${ }^{9}$ It is promoted by those who have decided that public pension funds (state or local) should invest some percentage of the assets within their own boundaries, "where it will do our own people some good."

Such required local investment is a very tempting solution to what may be either temporary or very basic economic problems. It may be absolutely necessary in a particular situation, although any reasonable standard of "necessity" tends to crumble very quickly in the political arena where such programs are formulated. The problem is that such programs are likely to postpone adjustments that are inevitable. Postponement makes the ultimate adjustment more difficult and leaves people less well-equipped (psychologically or otherwise) to cope.

Our experience with Japanese imports (TVs, autos, etc.) in recent years provides a good example. As a country without any of its own oil, Japan concentrated on fuel efficiency in its automobiles and otherwise. It emphasized productivity improvements to control

9 Jeremy Rifkin and Randy Barber, The North Will Rise Again: Pension, Politics and Power in the 1980's (Boston: Beacon Press, 1978). 
its labor costs and to provide better living standards. In the process it became a formidable competitor, making products we want, of equal or better quality, for less. Now we have had to adjust. It has been extremely unpleasant, but there was really no choice. We would probably be better off today if we had faced up to this adjustment process many years ago!

Thus, there are parts of the "social investment" movement that do not emanate from a broad perspective as to what is in the real "interest of the participants." But the genuine concerns that underlie this movement really should search for that broadened perspective. Those involved should not yield quickly to the temptations of what may be expedient, so long as there are better alternatives. Reorienting local activities to products and services that have better markets, lowering taxes to attract new investment in the area, accepting lower wages to keep somewhat marginal enterprises going and identifying inherent strengths are good examples.

Finally, this kind of "social investment" approach tends to become epidemic. It will not remain an isolated phenomenon. Reciprocity will take hold! If your state takes action that withholds funds that might have otherwise come to mine, mine will do the same to yours. And so on. It's trade protectionism in another form.

\section{Hopes for the Future}

As those who are charged with responsibility for pension funds must deal with the many issues that bear on the "interest of the participants," let us hope they will be heavily influenced by the broadened perspective herein discussed. Furthermore, as judges and juries have occasion to examine such endeavors - not too often, I hope - I expect they will recognize the importance of the broader view. 


\section{APPENDIX}

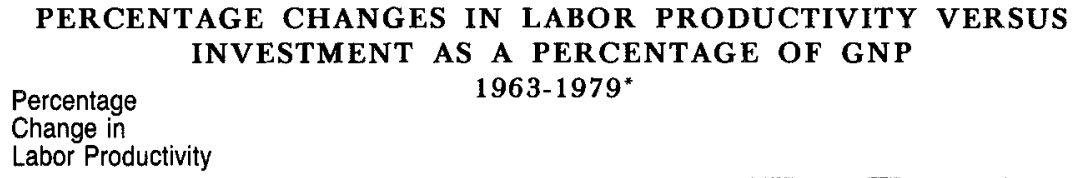

Percentage

Change in

Labor Productivity

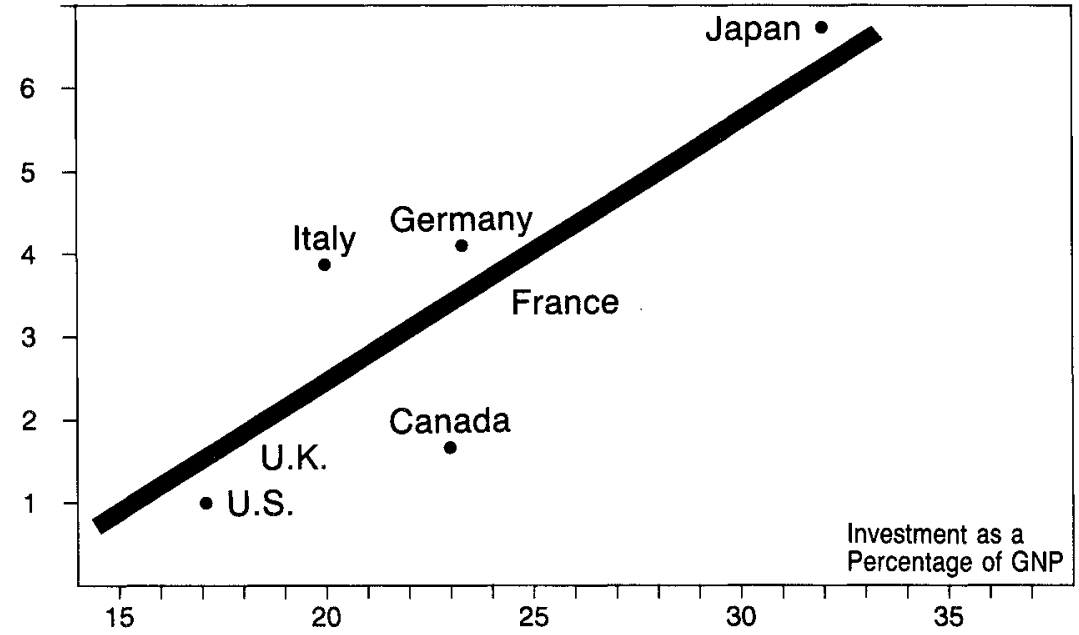

*The following regression was used: percent change in productivity $=-4.0295+0.32397$ (1/GPN); standard deviations of 1.78697 and 0.076735 , respectively, and $R^{2}=0.78$.

Investment figures calculated through 1978 only.

SOURCE: Robert M. Dunn, Jr., Economic Growth Among Industrialized Countries: Why the United States Lags (National Planning Association Committees on Changing International Realities, May 1980), p. 15.

\section{PERSONAL SAVINGS AS A PERCENT \\ OF DISPOSABLE INCOME \\ 1970-1979 AVERAGE}

Percent

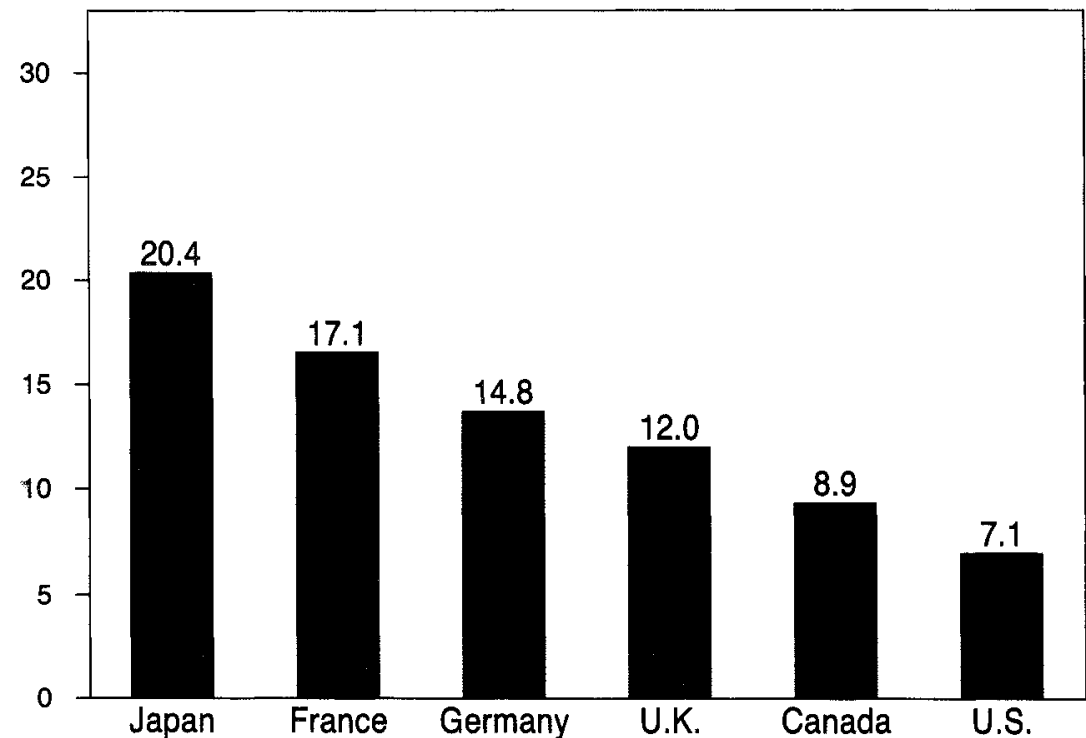

SOURCE: U.S. Department of the Treasury, Office of the Secretary, "Background Charts and Graphs" in The President's Tax Policy (Washington, D.C.: U.S. Government Printing Office, February 18, 1981), n.p. 


\title{
THE PRIVATE AND PUBLIC PENSION SYSTEMS \\ IN RELATION TO SAVING, INVESTMENT AND GROWTH
}

\author{
James Tobin
}

Retirement savings, whether designated as such or not, are the major source of savings for our economy. In fact, it was shown by Franco Modigliani, and confirmed by simulations of my own, that the entire stock of wealth in the United States could be simply the accumulation of retirement savings.

This is a life cycle process. Workers save and acquire assets during their active working years and then as old people sell these assets to finance their ongoing consumption. Thus, the stock of wealth is exchanged between generations, from retired workers to young workers saving for their own retirement. In a growing economy this pattern implies a growing accumulation of wealth. Every generation brings more young workers, and they have higher incomes than their predecessors. Their saving will be greater than the contemporaneous dissaving of the retired.

This is not to deny the importance of other motives for saving: for bequests to heirs, for contingencies such as ill health, the loss of a job, or the loss of other income. The several motives interact with each other; the savings of an individual can serve several purposes at once.

Organized retirement saving has been growing steadily throughout the postwar period, in both governmental and private pension plans. The latter amounted to twelve percent of individuals' wealth in 1957 and grew to twenty percent by 1980 . When life insurance reserves are added, privately organized retirement savings amount to some thirty-five percent of total financial wealth.

The major question which concerns economists is whether, and to what extent, organized retirement savings add to total national savings and aggregate capital formation. Maybe organized retirement savings simply substitute for savings that individuals on their own would have done in other forms. Since organized retirement savings are compulsory - or semi-compulsory, as a condition of employment - they should be expected to have an impact on the country's capital formation. Some people would not have saved so 
much on their own. Yet, organized savings surely do in some degree serve as substitutes for voluntary individual savings; it would be an error to regard all increases in pension plans as net increases in the nation's savings.

Compulsion is one reason organized retirement savings are not a complete substitute for voluntary savings. Another reason is liquidity. The worker's equity in a pension plan and his expectation of future Social Security benefits are both illiquid assets. He cannot consume these assets in advance - or even use them as collateral for a loan. Finally, there is only a loose connection between contributions to the plan and the eventual benefits paid by Social Security and most private pension plans.

Other reasons are intrinsic in the purposes for which pension plans were started and gained social acceptance. Capital markets are not perfect. Many individuals with limited means do not have the opportunity to invest in the longer term instruments appropriate for retirement savings. Now most workers have access to these capital markets via their pension funds. The funds pool many workers' contributions so as to invest them more effectively. There is also the Christmas Club syndrome: many people really do like to be forced to save for retirement. They want to be spared their own temptations to spend, even though many economists would regard it as irrational for the worker not to keep his options open.

There was an unusual development in the early days of Social Security. George Katona found that workers covered by Social Security saved a greater proporation of their incomes than did uncovered workers. We might rationalize their behavior by suggesting that Social Security, especially when combined with pension plans, made them the first generation to have within their reach an old age independent of their children. Once they say this possibility, they began to save more so as to make independent retirement a reality.

However, this synergism between compulsory retirement saving and voluntary saving is probably no longer a significant factor. Now accustomed to the idea of an independent retirement achieved through Social Security and private pension benefits, people save less in other forms. This would not affect national saving as a whole if the plans were funded, so that the government or the employer saved the workers' contributions on their behalf. But in fact Social Security is not funded, and many private plans are not either.

A major issue that has divided economists is the effect on national saving that results from the fact that Social Security is not funded, but rather is a pay as you go plan. Martin Feldstein is the most 
prominent economist to raise this question. He argues that workers can foresee Social Security benefits, and accordingly save less in other forms. Meanwhile the government spends their payroll tax contributions to pay the elderly beneficiaries of the system.

The amount of wealth required to provide the equivalent of Social Security benefits would exceed several trillions of dollars by the year 2000 . Thus the nation's stock of productive capital would be that much larger if the Social Security program were fully funded - or if workers provided for the equivalent pensions by fully funded programs. The same critique applies to the Federal Civil Service and military pension plans, which are unfunded, and also for the unfunded portions of other pension plans.

Feldstein's criticism of "pay-as-you-go" has merit, but he has exaggerated. Modigliani's life cycle theory of saving should not be taken too literally. There are other motives for saving besides retirement. As I have already noted, one such motive is to leave a bequest. It is quite possible that the Social Security taxes paid by the young workers enable retired workers to use their Social Security benefits to conserve or even build up assets, which they return to the younger generation in bequests instead of using them for additional consumption. This point is strongly urged by Robert Barro. He assumes that there is a basic intergenerational compact within any family and that it will remain intact no matter how the government tries to redistribute consumption between the generations. The family offsets the government's actions by changes in their voluntary saving behavior and by intergenerational transfers. Essentially, the family seeks to maintain a balance between the well-being of the existing generation, both workers and retired, and the well-being of their heirs.

Empirical budget studies indicate that old people generally do not exhaust their capital as life-cycle theory predicts. Old people are risk-averse and establish reserves against the frightening possibility of severe medical bills. Their risk aversion means that they over-provide for this contingency, knowing that if they die without major medical and custodial expenses, the residual surplus goes to their heirs anyway.

Furthermore, as mentioned above, the illiquidity of retirement savings means that many workers just aren't in a position to offset the impact of Social Security taxes or of premiums levied on them for other retirement programs. They do not have surplus assets that they can consume. For them, the prospect of Social Security benefits and other pensions is not a complete substitute for savings which would otherwise have been made. 
Feldstein says that if Social Security was a funded system its surpluses would go into capital formation. Here one must consider the impact of Social Security on federal fiscal policy. The Unified Federal Budget was adopted in 1968. Before then, Social Security receipts and outlays were not included in the "administrative budget," the budget which was the focus of fiscal policy and the political concerns about deficits and budget balance. (In 1961 and 1962 we in the Kennedy Administration wanted to slip some fiscal stimulus in to the economy without affecting the administrative deficit. Social Security payroll tax increases were deferred and benefits increased.) Under unified budget accounting, surpluses in social security accounts might be used to run larger deficits elsewhere. If one thinks that the President and Congress aim at an overall deficit, then it is their fiscal policy, not the specifics of social insurance, that affects capital formation. The present Federal Budget deficits are using a substantial portion of the public's savings, and Social Security is discussed in that context. In 1993 we are scheduled to return to the old system of separate accounting, and that may alter the situation.

In any case, we need to ask what determines the level of a nation's investment. Classical economists thought it was thrift, the nations's propensity to save. Keynes thought the situation was usually the other way round, that investment determined savings. Investment results from businessmen's calculations of what additions to capital stock will be profitable. High investment brings a strong business expansion, which will then result in income sufficient to generate the savings necessary to finance the investment. Both the classical economists and Keynes were correct. There have been times when the economy has been held back by insufficient capacity resulting from inadequate savings. At other times, however, there have been recessions where excess capacity indicated that the problem was inadequate spending, not inadequate saving; investment was held back by lack of profitable investment opportunities.

The funding or nonfunding of retirement benefits cannot make much difference to the nation's stock of wealth unless Feldstein is correct in assuming implicitly that the economy operates at full potential at all times. If there were full funding not offset by federal fiscal policy, there would indeed be an increase in the national propensity to save. Yet, there is no reason to think that this would automatically be used for investment in capital stock. It is possible that an increased propensity to save would simply result in more slack in the economy. To be channeled into real investment, a full funding of Social Security would have to result in substantial reduction in 
real interest rates. This would not happen automatically; it would require the help of the Federal Reserve.

It is hard to determine the effects of unfunded Social Security empirically. Total net private savings, excluding Social Security taxes, have not changed a great deal since World War II if measured relative to GNP, nor do successive budget studies show much change in such savings by household. Saving rates are very consistent, with the upper income percentiles saving more and the lower income percentiles having consistently lower saving rates.

Full funding of retirement plans is a good idea in principle. If we could rewrite history, full funding would be better. However, it is hard to show that the absence of funding is responsible for any economic disaster - nor would one expect that the initiation of funding would now result in any economic miracle. Anyway building up a fund would require sacrifice of consumption by the generations who had to pay taxes both for their own future retirement benefits and for those of their senior contemporaries.

There is some evidence that investment has been lagging in recent years, as shown by the following table:

\author{
Net Investment As A \\ $\underline{\text { Percent Of Net National Product }}$
}

1979

1973

1967

1965

1948

1929
$7.4 \%$

6.1

8.0

10.0

8.0

6.3

11.7

7.8

The years in this table were chosen because they are all peak years in the business cycle when investment was most likely to be constrained by saving. While this history provides some evidence that 
investment has fallen relative to potential national product, the fall is not large. If we compare the stock of reproducible wealth in relation to the GNP, we find that in 1979 wealth was 2.4 times GNP, while it was 2.9 in 1929. Other series show some tendency for business capital-to-output ratios to go down, but nothing very dramatic.

The outlook for saving and investment at this time is positive. The changes in depreciation and the liberalization of the investment tax credit will add to corporate investment. The extention of IRAs to everyone may also increase savings. Retirement savings should be invested in long-term capital assets such as stocks and long-term bonds. Most of the IRA funds, however, will probably go into bank administered accounts and be used as short-term capital.

To sum up, retirement savings are a major source of savings for our economy. The enormous growth of funded pension systems has accounted for much of the nation's capital formation in recent years. The impact of the federal government's pay-as-you-go Social Security system is hard to assess. A funded system might be better, but the impact of Social Security cannot be detached from the general question of the federal deficit. Smaller deficits when the economy is operating at potential would contribute to national saving and capital formation. Altogether, the economy is not currently suffering from a shortage of private-sector saving.

\section{References:}

Franco Modigliani. "The Life Cycle Hypothesis of Saving, the Demand for Wealth, and the Supply of Capital." Social Research vol. 33 , no. 2 (1966).

James Tobin. "Life Cycle Saving and Balance Growth." In William Fellner, editor, Ten Economic Studies in the Tradition of Irving Fisher. New York: John Wiley and Sons, 1967.

Martin Feldstein. "Social Security, Induced Retirement, and Aggregate Capital Accumulation." Fournal of Political Economy, 82 (September-October 1974): 905-26.

George Katona. The Mass Consumption Society. New York: McGrawHill, 1964.

Robert Barro. The Impact of Social Security on Private Saving: Evidence from U.S. Time Series. American Enterprise Institute, 1978. 


\title{
GOALS IN AN INFLATIONARY WORLD
}

\author{
Robert D. Milne, CFA
}

We will discuss a very simple subject - the goals of a pension fund. As pension fund investment managers, we usually focus on the immediate goals stressed in the formalized statements of investment policy and strategy. We recognize that these in reality reflect the counsel of the actuaries and the collective wisdom of the management of the employer. Yet, in the end, the ultimate goals of any pension fund should be to serve the best interests of the workers. When Congress passed ERISA in 1974, it stated that all pension plans should be managed "in the interest of participants."

The interests of all participants in a pension plan are basically the same, the provision of an adequate source of retirement income. Clearly this is the chief aim of those participants who are already retired. Active participants in the pension plan similarly have this as their main objective since they hope to retire someday. A pension, however, should not be considered to be the only source of retirement income. The typical retired worker receives considerable income from Social Security benefits and possibly significant amounts of investment income from savings accumulated during working years. Fortunately, this means that the pension doesn't have to do the whole job of providing retirement income.

This leaves us with a more precisely defined task - to consider the most important factors in determining realistic goals for retirement income and then to consider the ways in which these goals might be met by the three main sources of retirement income, including the pension.

Perhaps one might begin with an optimistic goal that retirement income should be as high as the worker had before retirement and that it should continue through the retirement years at the same level in real terms, after adjusting for inflation. This is a much too ambitious goal. To begin with, there will probably be rather large tax savings once the worker retires. To a lesser extent there will be savings in work-related expenses such as commuting. The President's Commission on Pension Policy made some studied estimates which indicated that if a worker made $\$ 10,000$ per year, the equivalent retirement income would only have to be about seventy-three 
percent of the preretirement income. At the $\$ 20,000$ annual income level the equivalent retirement income ratio would be sixty-one percent and this would drop still further to fifty-one percent at the $\$ 50,000$ per year level.

The main reasons for these sharp reductions are that Social Security benefits aren't significally taxed under current law and that a number of special provisions in both the Federal tax code and in most state tax codes favor the retired. In summary, it would appear that a retirement income in the area of fifty to seventy percent of the preretirement income would be a goal that would permit the retired work force to enjoy a standard of living as high as the active work force.

This brings us to a brief look at the role that Social Security can be expected to play. The average U.S. worker can expect to receive a Social Security check equal to about forty percent of his pay at retirement. The formulas determining Social Security benefits are complex. Benefits are related to average pay during the working years, with an inflation adjustment to increase pay in earlier years so that the average more closely approaches the pay level at retirement. Benefits do not go up precisely in line with average pay. The table below gives a general impression of Social Security benefits paid in 1982 .

TABLE 1

SOCIAL SECURITY BENEFITS FOR AN INDIVIDUAL IN 1982

$\begin{array}{lll}\begin{array}{l}\text { Average Adjusted } \\ \text { Annual Income }\end{array} & \text { Monthly Benefit } & \\ \$ 32,400 \text { or more } & \$ 709 \text { per month } & =27 \% \text { of pay } \\ 16,000 & 631 & =40 \\ 10,000 & 480 & =58\end{array}$

If the worker has a spouse not entitled to Social Security benefits in his (her) own right, then the spouse receives a benefit equal to onehalf of the individual's benefit - for example an additional $\$ 354$ per month for a spouse of a worker in the top bracket. The net result is that the average American family with only one working spouse will receive Social Security benefits nearly equal to sixty percent of the worker's pay immediately before retirement. This is a major part of the sixty to seventy percent of preretirement income needed to keep the worker's spendable income constant. Now that the majority of families have two spouses working, the norm is for Social Security to provide forty percent of the workers' combined pay, a sharper drop than for the couple accustomed to having only one paycheck. 
Thus, for the average worker retiring in the next decade, this leaves a gap of about one-quarter of preretirement pay to be made up by a pension and from the worker's investments accumulated during the working years (probably a moderately sized savings account of some variety).

About half of the workers in this country are covered by pension plans. This proportion has been increasing over the years and is likely to continue to grow. The main goal for retired workers is to see their income continue upward in real terms during the retirement years.

It would be a splendid achievement to keep up with inflation, but even that is inadequate. Productivity gains in the economy mean that income per capita tends to rise faster than inflation, making for gains in real income. Personal spending always keeps up with income-with new technologies bringing forth a stream of new goods that soon become necessities. There was a time when home electronics meant a radio. Then television came, followed by color television and now perhaps a video tape recorder or home computer - with more to come in the future. Much the same pattern is followed throughout the economy.

Therefore, an idealistic view of retirement income should be to keep up with increases in disposable personal income per capita. The Bureau of Labor Statistics makes periodic studies of an appropriate budget for a family of four. Oddly enough, over the years they always come up with a budget that is within three to four percent of the median family income at that point in time. This is human nature. What is required is what the average family earns and spends. Gains in productivity over the years have tended to average close to three percent per year. If these trends continue, a worker retiring at age sixty-five will see the median family income in inflation-adjusted dollars increase by seventy percent by the time he (she) reaches eighty-five. Hardly any retired workers will have increases in retirement income anywhere near that pace.

The next factor to consider is what will happen when the spouse of a retired worker dies. Often this will be a financial benefit for the survivor. Obviously the surviving spouse won't have to spend as much as when both were alive. The Bureau of Labor Statistics calculates that a single retired person can live on fifty-five percent of the income of a retired couple. This is probably a low estimate. The White House Conference on Aging proposed that seventy-five percent would be an appropriate measure. Social Security benefits are reduced by one-third when a spouse dies, indicating that the Con- 
gress believes that the appropriate requirement is sixty-seven percent for the surviving spouse. In any event, income requirements will probably drop somewhere in the area of thirty to forty percent. Retirement income ought to hold up reasonably well with most pensions continuing at the previous level-or reasonably near that level - and investment income also holding firm now that estate taxation at the Federal level has been eliminated for the estate of the first spouse to die.

The main question is what level of real income will a pension provide during the retirement years. Figure 1 shows the real value of a pension assuming that inflation continues in the future. The actuaries calculate that a fixed dollar pension can be granted in the area of twelve percent per annum of the fund available for the retiree. The real value of the monthly pension check will depend upon the rate of inflation. If inflation continues at rates similar to those of the 1970-80 decade, the real value of the pension will go down rather fast. The average life expectancy of a male age sixty-five is approximately thirteen years, and when the life expectancy of the spouse is also factored in, the average life of a pension is about twenty years. If inflation proceeds at six percent, the real value of the pension after twenty years will be only thirty percent of the starting level. If inflation should proceed at ten percent, the real value after twenty years would be only fifteen percent of the starting level. It is hard to say that a reduction in the real value of a pension to that extent is a humanly acceptable definition of "the interests of the participants."

FIG URE 1

REAL VALUE OF PENSIONS

FIXED AND INDEXED PENSIONS

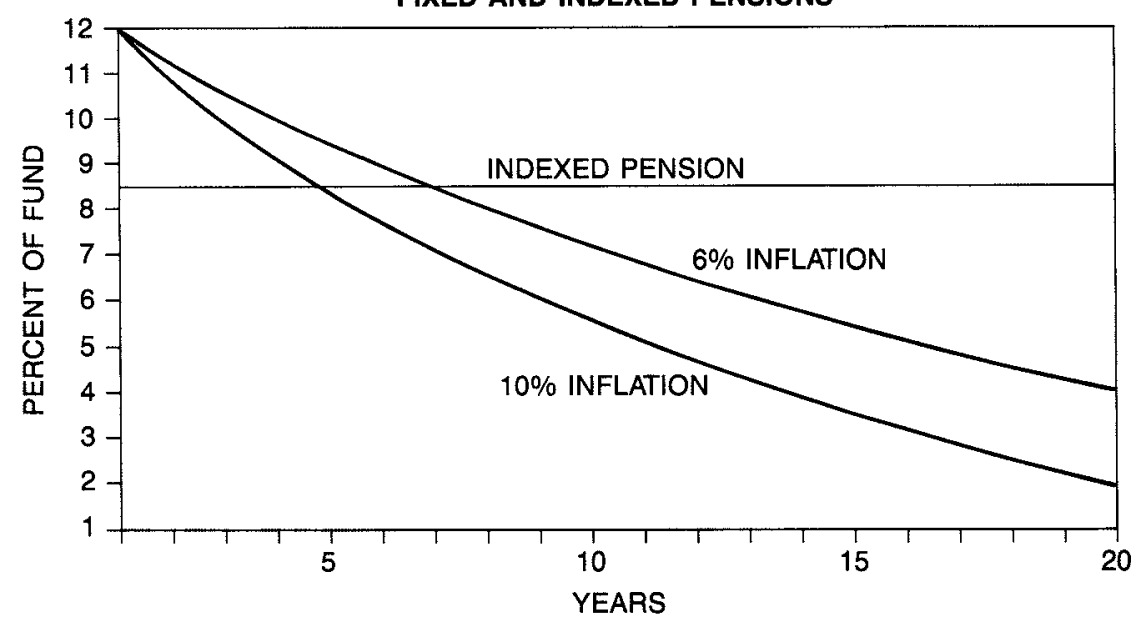


Perhaps one might say that the retiree should save part of the pension checks in the early years to accumulate a fund that can be used in the later years when inflation erodes the real value of the pension. Although this might be sound theory, it hardly accords with reality. One might consider as an alternative the possibility of a pension indexed against inflation. Figure 1 shows that an indexed pension would retain its real value over the years, but that it would start out at a lower rate than a pension expressed in nominal dollars. The indexed pension would probably have to start out at about seventy percent of the value of a fixed dollar pension. There are a number of arbitrary assumptions behind this statement, the major one being that a real return of six percent after adjustment for inflation can be earned on the fund devoted to the retiree. If such a revolutionary change in pension payments were made, the investment manager would probably have to concentrate on equities to fund indexed pension payments rather than on dedicated bond portfolios designed to match fixed dollar pension requirements.

While the difficulties are immense, the basic problem is to provide a real flow of retirement income that will match the real needs of the retired workers. This is not a theoretical problem. It is a real one. Most pension plans allow the worker the option of taking a full pension for the balance of the worker's life or taking a lesser amount covering both the worker's life and the life of the worker's spouse. A similar option for indexed pensions might be feasible. Most workers are realistic enough to understand that provision for a spouse is in order and there is no reason to expect that they would not recognize the impact of inflation.

At this point we must consider another major factor influencing what benefits can be paid to retired workers. Figure 2 illustrates population projections for the next seventy years as they influence the proportion of the population that will be retired. We all know that people are living longer than they used to. Moreover, if people take better care of their health and if medicine continues to advance, mortality should continue to decline. The nation will probably not be able to afford a continually expanding health care effort, but further gains in life expectancy should still continue.

The message of Figure 2 is that the proportion of the population made up of retired workers is in the process of expanding from twenty-three percent of the population in 1960 to twenty-nine percent by 2010 . This reflects a half century of improved life expectancy. Obviously this presents a burden on the active work force, but the burden will grow at a manageable level for the next thirty years. However, at that point the Pepsi generation will start to retire and 


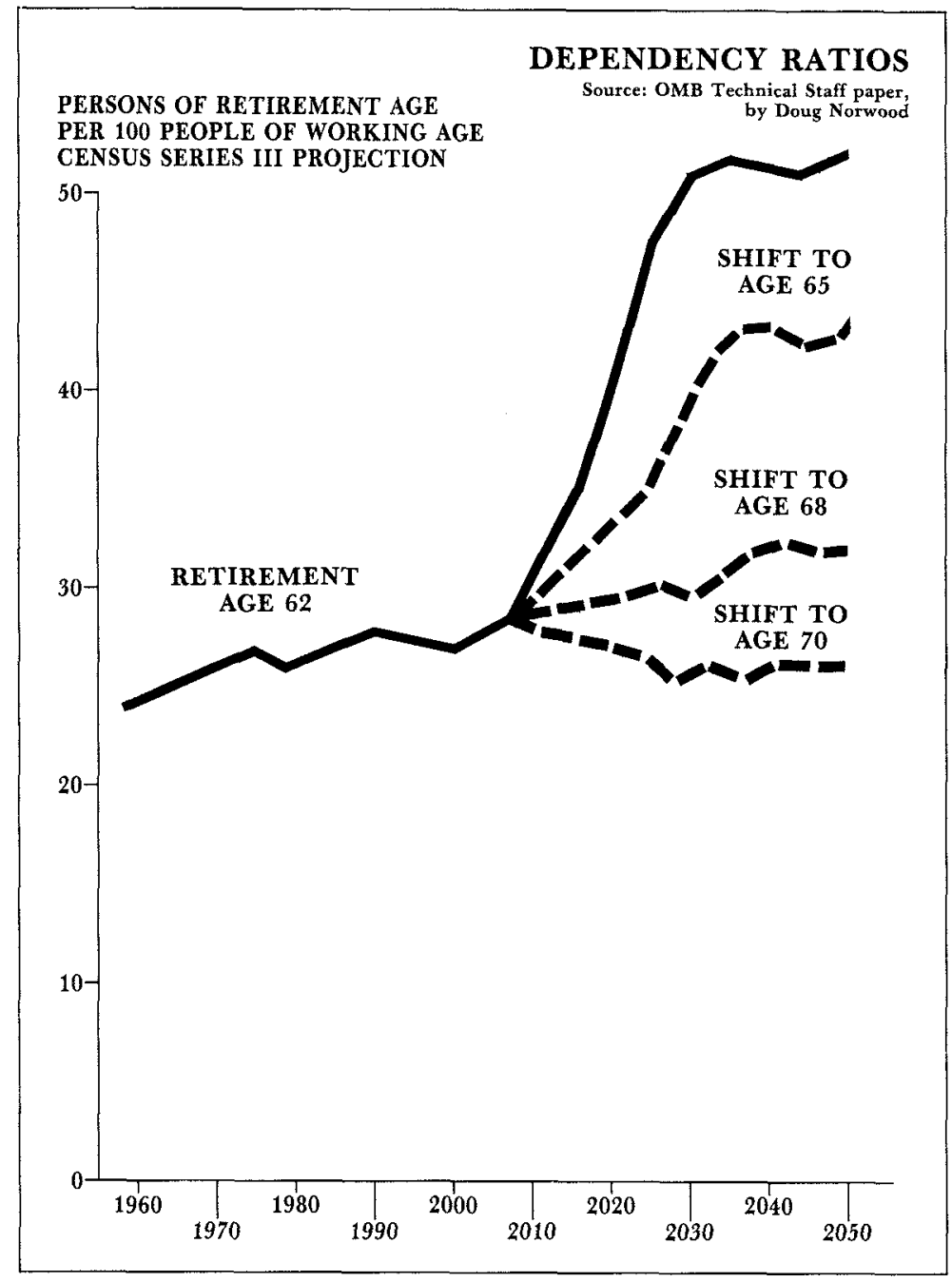

the next thirty years will see major problems if retirement plans are not changed. The chart suggests that the problem will go away if workers are willing to continue on their jobs longer. If they are willing to defer the retirement age by eight years, the problem will go away completely - and lesser shifts in the age at normal retirement would be of some assistance.

The one thing that is certain is that the problem of the dependency ratio cannot be cured by investing more effectively. The squirrel stores up nuts to use all winter long, but humans cannot. A retired worker might say that his auto and washing machine will last forever, but in reality the retired community cannot live off of commodi- 
ties produced during the working years. The physical goods and services will have to be provided by the active working force. The question is then one of transfer payments. How much of the nation's wealth can be transferred from the active workers to the retired workers?

Social Security benefits are clearly a transfer of funds between the generations. Pension payments in reality are essentially the same, with the active workers receiving less in current paychecks in order to finance pension plans. Direct investments by the retired work force are also a charge against the active workers. Through banks and other financial intermediaries the active workers borrow from the retired workers in order to finance houses, cars and other tangible assets. The active workers then make interest payments which flow through the intermediaries to the retired workers.

In conclusion, the simple story is that there is a major problem facing the retired worker. In the past the risk of inflation has simply been passed on to the retired worker. Retired workers are living longer and inflation has been much worse than in past generations. No doubt attempts will be made to pass on the risk of inflation to the Federal Government, but there are obvious limits here. Even the inflation adjustments for Social Security benefits and for other retirement benefits paid are a serious strain on the Federal budget. This leaves the nation's pension funds as the logical institutions to respond to the human needs of the retired work force by creating the option of providing indexed pensions. The practical problems in implementing them will be great - and the investment managers will have to face a major reorientation in investment policy and strategy - but the real needs of the participants will have to be met. 


\section{FUNDING PENSION LIABILITIES: \\ EMPLOYEE VERSUS FIRM PERSPECTIVES}

by

Robert S. Kemp, Jr., CPA

\section{Introduction}

The growth of pension funding points to its importance throughout the American economy. Assets in private pension funds grew between 1970 and 1980 from $\$ 151.6$ billion to $\$ 450.7$ billion, an annual growth rate of eleven percent. The importance of defined benefit plans to corporate sponsors is likewise visible. In a 1983 survey of the Fortune 100 companies twelve percent of the firms had pension assets in excess of the book value of corporate equity; pension assets were greater than twenty-five percent of the book value of corporate equity for half of the firms. ${ }^{1}$ With respect to vested funding status (pension assets minus the present value of vested benefits), most of the companies had a vested funding status which was within $+/-$ ten percent of net worth. However, there were notable exceptions including Lockheed's vested funding status of 167.8 percent of net worth and Bethlehem's - 67.1 percent.

As important as pension funding is, pension funding theory and management practices are often inconsistent, particularly as they relate to questions of when and by how much a corporation should fund its pension fund. These are complex and confusing questions, because they are a function of so many assumptions (e.g., mortality rates, interest rates, etc.) and because of the multitude of regulations, allowable accounting procedures for pensions, and pension plan alternatives. These questions are further clouded by the different perspectives that the employee and the firm may have about pension funds.

Since Mennis and Clark, Stone, and others have clearly discussed the complex and confusing issues alluded to above, this paper is

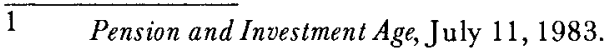


devoted to the problem of differing pension perspectives. ${ }^{2}$ Although the employee's versus firm's perspective is affected by so-called pension complexity and confusion issues, it is primarily rooted in their differing objectives. Safety of pension benefits is the chief concern of the employees while firm value dominates the firm's perspective. Although often congruent, securing the safety of pension benefits and maximizing firm value are not always viewed as complementary. Furthermore, while safety of benefits appears synonymous with full funding and investing pension funds in low risk investments, maximizing firm value is far more perplexing.

\section{Pension Liabilities and Firm Value}

An unfunded pension liability is in essence a firm borrowing from its employees. Unfunded pension liabilities are the difference between the present or current value of future retirement obligations and the current value of funds set aside to pay these obligations. As a financial obligation, an unfunded pension liability should theoretically affect the value of the sponsoring firm.

Kemp, McDonald, and Nichols detail the argument supporting the relationship between the value of a firm and its pension liability. ${ }^{3}$ Pension liabilities have a direct effect on the risk of a firm, which affects the required return of the stockholders of the firm. This in turn affects the value of the firm. As the financial leverage created by the pension liability increases relative to the equity of a firm, the required rate of return should increase. Such a position is an extension of the works of Hamada, Rosenberg and McKibben, Thompson and others, expanding the definition of debt to include pension liabilities. ${ }^{4}$ This position is congruent with Sharpe's work

2 Edmund A. Mennis and Chester D. Clark, Understanding Corporate Pension Plans (Charlottesville, VA: The Financial Analysts Research Foundation, 1983); and M.S. Stone, "A Survey of Research on the Effects of Corporate Pension Plan Sponsorship: Implications for Accounting," Journal of Accounting Literature 1 (1982): 34-57.

R. Kemp, B. McDonald and W. Nichols, "Do Unfunded Pension Liabilities Provide Relevant Information to the Investor Concerning the Firm's Risks?" Journal of Employee Benefits 6 (September 1981): 38-44.

R.S. Hamada, "The Effect of the Firm's Capital Structure on the Systematic Risk of Common Stocks," Journal of Finance 27 (May 1972): 1-13; D.J. Thompson, "Sources of Systematics Risk in Common Stock," Fournal of Business 49 (April 1976): 173-188; and B. Rosenberg, and W. McKibben, "The Prediction of Systematic and Specific Risk in Common Stock," Journal of Financialand Quantitative Analysis 8 (March 1973): 317-334. 
showing that the full funding of pension liabilities is best, due to tax consequences. ${ }^{5}$

When market imperfections are taken into account, we cannot extend this theory directly beyond conventional forms of debt (e.g., bonds) and into pension liabilities. Pension liabilities are different from conventional debt because of measurement problems and because of the interface between a firm and its pension fund. Its contingent nature and the difficulty in measuring pension liability is well documented in the literature. ${ }^{6}$ Interfacing problems are not as well documented, but are just as perplexing.

Interfacing problems concern the nature and extent of a firm's obligation to its pension fund. If a firm's pensioned employees are unable to receive promised (i.e., vested) benefits, what are the firm's obligations? Are the firm and its pension fund one entity in reality, or are they separate entities operating in a total, arm's-length relationship? What are the legal and financial realities of this relationship?

Legally, the pension fund and the sponsoring firm are viewed as separate entities. To protect the interest of all parties, the Department of Labor and the Public Benefit Guarantee Corporation (PBGC) are charged with overseeing the independence of the pension fund and firm. The Employee Retirement Income Security Act (1974) and subsequent amendments clearly establish the rights, responsibilities, and relationships of all parties. Bodie, Light, Morck, and Taggart label this perspective the "traditional perspective."7 According to Bodie et al., "pension funds are entirely separate from the corporation and its shareholders and should be managed without regard to either corporate financial policy or the interests of the corporation and its shareholders. From this perspective, funding decisions should be based solely upon the expected future stream of

5 W.F. Sharpe, "Corporate Pension Funding Policy," Fournal of Financial Economics 3 (June 1976): 183-193; and F. Black, "The Tax Consequences of Long-Run Pension Policy," Financial Analysts Fournal (July-August 1980): $21-28$.

A.F. Ehrbar, "Those Pension Plans Are Even Weaker Than You Think," Fortune 96, (November 1977): 104-108; and T. Fratar, and B. Gilber, "A Pension Cost Accounting and the Implications of Unfunded Vested Liabilities for Financial Statement Analysis," Journal of Commercial Bank Lending 59 (July 1977): 32-44. in Corporate Pension Plans: An Empirical Investigation," NBER Working Paper No. 1315 (March 1984). 
employee pension liabilities, irrespective of corporate financial condition and/or policy."

These authors second perspective on pension funding, the "corporate financial perspective," states that "defined benefit liabilities are just one more set of fixed financial liabilities of the firm. Pension assets, while collateral for these liabilities, are really just assets of the firm in that the surplus/deficit belongs to the firm's shareholders. This integrated perspective is then concerned with how to manage the firm's extended balance sheet, including both its normal assets and liabilities and its pension assets and liabilities, in the best interests of the shareholders. This view explicitly ignores the interests of the beneficiaries, in part because their defined benefits are insured by the PBGC anyway. From the corporate financial perspective, then, the beneficiaries are protected by the government, and the corporate pension decisions become what amount to a game between the corporation and various government agencies and interests, a game that can be and should be thought of as an integral part of corporate financial policy." 8

The traditional and corporate financial perspectives are determined by the financial considerations of the firm. The traditional perspective, that of separate entities, implies that only the unfunded pension liability should affect the firm. (An unfunded pension liability is the present value of vested benefits less the current value of the pension fund assets.) Such a perspective is well documented in Accounting Principle Board Opinion No. 8 and Financial Accounting Standards Board Interpretation No. 3. When a pension fund thus is seen as an entity independent from the firm, the amount owed to the pension fund is all that matters. Contrasting this is the corporate financial perspective which holds that the gross pension liability is the relevant obligation of the firm, implying that the pension fund and firm are a single entity. (The gross pension liability is the present value of vested benefits.) Such a perspective sees the pension fund as an extension of the firm and the fund's gross liability to pensioned employees as a liability of the firm.

Within these two perspectives are two subcategories for measuring the financial leverage created by a pension liability. The first acknowledges the close relationship of pension funding and expending pension costs. This category reduces equity by the amount equal to the pension liability. ${ }^{9}$ A debt ratio adjusted for an unfunded pension liability increases debt, but does not change total assets.

$8 \quad$ Z. Bodie, et al., op. cit.

9 Martin Feldstein, National Bureau of Economic Research Siudy of Unfunded Pension Liabilities, Harvard University, 1980. 
In contrast to this is the belief that a pension liability carries an implied asset to the firm (a pension put), and should not affect equity..$^{10} \mathrm{~A}$ debt ratio adjusted for a pension liability increases debt and total assets.

To date, research has only examined the effect of the traditional perspective. Oldfield, Feldstein, Seligman, Morck, Gersovitz, and Daley have examined the effect of an unfunded pension liability on firm value using varying measures of the unfunded pension liability. ${ }^{11}$ Each work supports the theory that unfunded pension liabilities appear to adversely affect firm value. In addition, Bodie et al. find that pension liabilities are systematically linked to company profitability through the choice of a discount rate and that the level of pension funding is positively related to companies' long-run profitability. ${ }^{12}$ Research to date thus supports the idea that funding pension liabilities adds value to the sponsoring firm.

Yet pension funds are often not fully funded. Although theory dictates full funding and research supports full funding, practice short of full funding persists.

\section{Safety of Employee Benefits}

Given that pension liabilities are not always funded, the safety of employee benefits must also be taken into account. So-called employees' safety is the single most important factor in the pension funding question. An employee can not be placed in a position of questioning whether or not he will receive his earned pension. The

10 J.L. Treynor, P.J. Regan, and W.W. Priest, The Financial Reality of Pension Funding Under ERISA. Homewood, II: Dow Jones-Irwin, 1976.

11 L.A. Daley, "The Valuation of Reported Pension Measures for Firms Sponsoring Defined Benefit Plans," The Accounting Review 1984: 177-198; Martin Feldstein, and Randall Morck, "Pension Funds and the Value of Equities," Financial Analysts Fournal (September-October 1983): 29-39; Martin Feldstein, and Stephanie Seligman, "Pension Funding, Share Prices, and National Saving," The Journal of Finance (September 1981): 801-824; M. Gersovitz, The Investment, Financing and Valuation of the Corporation, (Homewood, Illinois: Richard D. Irwin, Inc., 1962); and G. Oldfield, "Financial Aspects of the Private Pension System," Journal of Money, Credit and Banking (June 1983): . 
PBGC's responsibility is to insure that the employee's position is not jeopardized. As a go-between, the PBGC intends to insulate the employee and the firm, protecting employee interest while enforcing firm responsibility.

In financial terms, Treynor et. al. characterizes an unfunded pension liability as a "put option," where the firm has the option to put the firm to the employees. ${ }^{13}$ The relevant question for the employee is whether the value of that option is sufficient to cover the unfunded pension liability. In the vast majority of cases, the value of the option does exceed the unfunded vested pension liabilities greater than fifty percent of their book value. ${ }^{14}$ Thus, employee safety can be obtained without full funding.

\section{Reasons for Underfunding Pensions}

There are basically three reasons why economically healthy firms do not fully fund their pension funds. These reasons are not mutually exclusive but are in fact usually interelated. The complexity and confusion cited earlier which surrounds pension funding is one reason. The precautionary need for funds in the firm and firm liquidity-safety concerns are another. Third is the question of the marginal cost of pension liabilities and the marginal benefits the firm receives from these "borrowed" funds.

As earlier noted, complexity and confusion exist because of measurement problems and because there are a multitude of regulators, accounting alternatives, and plan design options. Recognizing that pension liabilities are real but subject to measurement error, firms may choose to fund pension liabilities minimally following legal guidelines (i.e., the PBGC and the Internal Revenue Service). Feldstein and Seligman imply that corporate managers do not understand the favorable effect on cash flow or they believe that the market is irrational when it reduces the value of the firm if the higher contributions increase the pension expense and thereby reduce earnings. ${ }^{15}$ In addition, changing economic assumptions (e.g., inflation, interest rates, etc.) create wide swings in pension liabilities. In volatile economic times, firms may chose not to currently fund pension liabilities given the possibility of future overfunding.

13 J.L. Treynor, et al., op. cit.

14 Pensions and Investment Age, July 11, 1983.

15 Martin Feldstein and Stephanie Seligman, op cit. 
Second, just as the firm's decision to fund a pension liability is a function of earnings, financial leverage, legal constraints, etc., it is also a function of a precautionary demand for funds and the firm's short-term liquidity needs. For example, according to The Wall Street Fournal firms may cut pension funding to fend off takeovers. ${ }^{15}$ Given the fact that funding can make firms choose between the long-term needs of the pension fund and the short-term needs of the company, firms may choose the latter. According to Bodie et al., and Myers and Majluf, firms experience a need for "financial slack." 16 Their decision can be justified as protecting employee welfare through firm preservation and job security, particularly in volatile economic times.

Finally, it is feasible for the marginal cost of pension liabilities to be less than the marginal benefits to be received from the investment of these funds. Maximization of firm value would direct the incurring of pension liabilities if this were the case. Tepper perceived the rationale for less-than-maximum funding as follows: "Any contributions made to the pension fund in excess of the minimum required by statutes deprive stockholders of capital that might be better employed in the business." 17

It should be noted that current theory stipulates that a firm should use conventional debt (bonds) in place of incurring pension liabilities. This would eliminate the second and third reasons for underfunding. However, it should also be noted that pension liabilities are often viewed as unconventional debt which provides the firm flexibility. Bonds and pensions liabilities are both debt, but beyond that point are very different (e.g., pension maturity is vague).

\section{Firm Value Versus Employee Safety}

Employee and stockholder interests have often been considered adversaries in the question of pension funding. The desire to safeguard employee benefits is seen to be at odds with the quest to maximize firm value. This paper outlines the theory and research

16 The Wall Street Journal (October 11, 1984).

17 Z. Bodie, J. Light, R. Morck, and R. Taggart, "Funding and Asset Allocation in Corporate Pension Plans: An Empirical Investigation," NBER Working Paper No. 1315 (March 1984); S.C. Myers, and N.S. Majluf, "Corporate Financing and Investment Decisions When Firms Have Information That Investors Do Not Have," Unpublished paper. Sloan School of Management, M.I.T (1983).

I. Tepper, "Taxation and Corporate Pension Policy," The Journal of Finance (March 1981): 1-14. 
behind this debate and attempts to reconcile these points to current practice. The question of whether or not to fund a pension liability must be based on the pragmatic concern for employee interest, firm value, and legal constraints.

The ultimate answer to pension funding questions must first address employee safety. Given the firm's levels of funding pension obligations, the investment strategy of the pension fund, the financial condition of the firm, and the posture of the PBGC, is the employee's safety put in jeopardy? If it is, there are problems which must be corrected. If employee safety is not jeopardized, then firm ownership interests should be considered.

Given a firm's orientation, full funding of pension obligations may or may not be in the interest of firm's owner. Although theory and research indicate that firm value is maximized by full funding, pension funding practice does not always coincide with theory. On the other hand, creating unfunded pension liabilities is not necessarily done at the expense of the employee. Employee and stockholder interests are typically not contradictory; rather they are complementary. The ultimate concern is whether an unfunded pension liability puts the employee in jeopardy. 


\title{
WHO IS THE VICTIM NOW?*
}

\author{
by \\ Linda J. Martin and A. James Ifflander, CFA
}

In pre-ERISA days, the employee, with no guarantee of pension benefits, was the potential victim of pension fund underperformance or failure. With the passage of ERISA, according to many articles in the financial press, the firm became the victim. Suddenly firms were liable for their pension obligations. This liability increased their debt levels, and at a time when bear market conditions were eroding their pension plan assets. Today, there appear to be three potential victims - the Pension Benefit Guaranty Corporation (PBGC), the employee and, possibly, the pension plan manager. Their role has been cast by government policy and by conflict between the groups involved in pension plans.

\section{The PBGC as Victim}

The PBGC, created by ERISA, insures defined benefit plans against default. If a pension sponsor terminates a plan that has insufficient assets to cover claims, the PBGC has legal claim up to 30 percent of the net worth of the firm. This claim has the priority of a tax lien.

The PBGC has been victimized by both good and bad economic conditions. The bad-times scenario is obvious. At worst, a recession may force a firm into bankruptcy. In 1982, a number of plan terminations resulted from bankruptcy, the largest being Braniff Airways.

Firms that can avoid bankruptcy may nevertheless decide to terminate their pension plans because of underfunding. The most basic decision-making criterion in financial management theory may suggest that, relative to continuation, plan termination is the lesser evil; that is, the value of the firm may be maximized by plan termination if the alternative is paying large amounts to correct un-

\footnotetext{
"Reprinted with permission of the authors and the Financial Analysts Fournal. (July/August 1984): 10. This article was printed in Patrick J. Regan's Pension Fund Perspective column.
} 
derfunding problems or paying large insurance premiums. ${ }^{1}$ For the same reason, a firm may prefer to terminate a plan and relinguish 30 per cent of its net worth to the PBGC rather than face the prospect of being saddled with an indeterminate pension liability in the future. ${ }^{2}$

In fact, the benefits to the firm from plan termination may actually exceed the cost of bankruptcy. In such a case, pension plan termination may be a secondary, but important, reason for filing for bankruptcy. The recent corporate practice (so far unchecked by court rulings) of using bankruptcy as a tool in labor negotiations is also likely to contribute to the incidence of bankruptcy, and plan termination. Neither the PBGC nor plan beneficiaries stand to gain from these trends.

The adverse effect of good economic times on the PBGC is less obvious. But a number of highly publicized terminations, or attempted terminations, have been the result of improved economic conditions. The assets of many pension plans have increased dramatically with the recent bull markets. Many other plans appear to be better funded because of an increase in the interest-rate assumption-i.e., the rate of return used to calculate the actuarial present value of accumulated plan benefits. The more pension fund assets (i.e., those already set aside) will supposedly earn in the future, the less the firm needs to contribute to the plan today; the result is a decrease in the expenses associated with current income levels. Although plan termination is a lengthy and costly process (primarily because of tax considerations), more and more firms are attempting to terminate their plans in order to free up excess funds for other purposes.

A\& $P$ was the first major firm to attempt to terminate an overfunded plan. It has been trying since 1981 to recover $\$ 200$ million in excess pension funds, with the intention of distributing the amount as dividends. This case has ramifications for taxpayers as well as for the PBGC and plan beneficiaries, because these funds would be taxfree to A\&P, thanks to the firm's large tax-loss carryforward. A class action suit by a retired $A \& P$ executive, demanding a share of the excess assets for employees, has so far stalled the termination appli-

1 T.C. Langetieg, M.D. Findlay and L.F.J. DaMotta, "Multiperiod Pension Plans and ERISA," Fournal of Financial and Quantitative Analysis, November 1982: 603-631.

2 A.F. Thompson, "Some Perspectives on Pension Valuation and Funding: Financial Management Considerations" (Paper presented at the Financial Management Association Meeting, October 15, 1983). 
cation in court. Occidental Petroleum, however, recaptured $\$ 400$ million from its pension plan in 1983; some of the funds went to pay for Occidental's acquisition of Cities Service. This tactic raises another public policy issue: Are pension funds being used to effect mergers, hence to lessen competition?

Some firms, rather than terminating plans, are switching from a defined benefit to a defined contribution plan. The PBGC does not insure defined contribution plans, hence sponsors of such plans do not pay insurance premiums to the PBGC. Employees covered by such plans have no guarantee as to the amount of their pensions and no insurance in the event of insolvency.

The flat-rate premium charged by the $\mathrm{PBGC}$ has also contributed to the agency's financial distress. Whereas private insurers vary their premium charges according to the insured party's risks, governmental and semigovernmental insurers charge flat-rate premiums. The PBGC initially charged one dollar per employee per year. In 1982, Congress denied the PBGC's request to increase premiums to $\$ 6.00$; the premium is now $\$ 2.60$. Optimistic projections suggest that premiums of $\$ 11$ are necessary if the PBGC is to become solvent by the end of the decade. Pessimistic scenarios (assuming the continued decline of the major smokestack industries, which currently constitute an appreciable portion of underfunded plans) indicate a necessary premium of $\$ 20$ to $\$ 30$.

Under the present flat-rate structure, firms with healthy pension plans subsidize firms with high pension default risk. This pricing scheme drives up the premiums for all firms, encouraging either plan termination or adoption of defined contribution plans. It is highly questionable, however, whether the PBGC could initiate a risk-related premium scheme even if it wished to do so. ${ }^{3}$ Current pension accounting allows five different actuarial cost methods, as well as variations in the wage and interest rate assumptions used to report pension liabilities. Given the widespread noncomparability in accounting, it would be virtually impossible for the PBGC to determine the riskiness of the plans it insures.

\section{The Employee as Victim}

Before ERISA, "the pension fund risks were borne by the pension beneficiaries, while the rewards from superior portfolio performance accrued to the plan sponsoring company." 4 Is the situation so dif-

3 Ibid.

4 J. Treynor, P.J. Regan and W.W. Priest, Jr., The Financial Reality of Pension Funding Under ERISA (Homewood, Ill.: Dow Jones-Irwin, 1976). 
ferent today, despite the modicum of security provided by ERISA?

Switches from defined benefit to defined contribution plans may be especially detrimental to employees. Defined benefit plans guarantee the employee a specified monthly income for life; in the event of firm failure, the PBGC guarantees this income up to $\$ 1,517$ a month. Under a defined contribution plan, employee benefits depend upon the investment performance of the contributions to the plan. Once again, risk is transferred from the firm to its employees.

Too, termination of overfunded plans, as noted above, allows the firm to benefit from the superior performance of its pension fund. Although ERISA allows a firm to terminate a plan and recapture excess plan assets, after paying participants what is owed to them at that point, the A\&P case shows that the issue is far from resolved. Union leaders and some Democratic politicians maintain that these funds belong to the employees, not the firm. The ownership of pension plan funds is likely to become more and more an issue of dispute if the financial condition of the Social Security system deteriorates further.

\section{The Pension Fund Manager as Victim}

An examination of the conditions described above suggests that the pension fund manager is in danger of becoming caught between the conflicting goals of firm and beneficiary. If the firm wishes to terminate the fund and use the excess assets for other purposes, for example, it might encourage the manager to seek higher returns, which would involve higher risk. Likewise, firms switching to defined contribution plans may encourage more aggressive management practices, inasmuch as the firm enjoys the benefits of excess returns while being able to lay off extra risk on the plan beneficiaries. Finally, the emergence of a risk-taking environment, together with the potential surplus of new investment managers, may be enough to force pension plan managers themselves to take riskier positions in order to attract clients. ${ }^{5}$ Increased competition, entailing greater risk-taking, is not in the best interests of employees.

There are no obvious solutions to these difficult problems. As a first step, however, the accounting profession might consider establishing one set of pension accounting standards for all firms. The PBGC might then be able to use accounting data to assess pension

5 P.J. Regan, "Crosscurrents in the Pension Picture," Financial Analysts Journal, January/February 1984, pp. 15-17. 
plan risk and determine risk-related premiums. Well funded plans would then face fairer and more manageable insurance costs. Further protection of potential pension victims may require structural changes in the private employee retirement system. 